\title{
neofilolog
}

Czasopismo Polskiego Towarzystwa Neofilologicznego

ISSN 1429-2173, elSSN 2545-3971, 2021, NR 57/1, 135-150

http://dx.doi.org/10.14746/n.2021.57.1.9

http://poltowneo.org/

Paulina Oczko

Katolicki Uniwersytet Lubelski Jana Pawła II w Lublinie https:// orcid.org/0000-0003-3292-020X

oczkopana@gmail.com

\section{Miejsce sprawności językowych na zajęciach języka specjalistycznego (na przykładzie polskiego języka medycznego)}

\section{The place of language skills in classes of foreign language for specific purposes (on the example of medical Polish)}

The aim of this paper is to present the results of two questionnaires conducted among thirty-eight participants of a language course in medical Polish for people from Belarus, Russia and Ukraine. The first survey (conducted before the course started) covered the following issues: (1) the participants' self-assessment of their knowledge of general as well as specialised (medical) Polish, (2) their expectations of the twentyhour course they were to attend, (3) their linguistic awareness of the need to develop the four linguistic skills in specialised language classes. The second questionnaire focused on the evaluation of the effectiveness of the classes and participants' own progress in learning Polish for professional purposes. The research was of a diagnostic and descriptive nature, and the findings signalled in this paper have given rise to broader reflections on the current state of research on the description of receptive and productive skills in teaching Polish as a foreign language for specific purposes.

Keywords: medical Polish , specialized language course, needs analysis, language skills

Słowa kluczowe: polski język medyczny, kurs języka specjalistycznego, analiza potrzeb, sprawności językowe 


\section{Wprowadzenie}

Jeszcze na długo przed wybuchem pandemii system opieki zdrowotnej w Polsce borykał się z poważnymi brakami w kadrze medycznej, które wówczas szacowano na prawie 70 tysięcy etatów. Kryzys epidemiczny trwający od marca 2020 roku uwydatnił problem niedoboru specjalistów, lekarzy pierwszego kontaktu oraz średniego personelu medycznego, z którym musiała zmierzyć się polska służba zdrowia. Próbując zaradzić sytuacji, podjęto kroki w celu zatrudnienia lekarzy z Europy Wschodniej. Chociaż zabiegają o nich również kraje Europy Zachodniej, szczególnie Niemcy, polskim atutem przyciągającym przyszłych pracowników jest bliskość kulturowa i językowa².

Mimo dość wygórowanych wymagań wobec lekarzy z Białorusi i Ukrainy od pewnego czasu odnotowuje się zwiększone zainteresowanie pracą w Polsce ze strony obywateli tych krajów. To z kolei prowadzi do powstania ośrodków (oraz platform internetowych) zajmujących się pośrednictwem pracy w sektorze ochrony zdrowia. Oprócz pomocy w uzyskaniu potrzebnych informacji oraz dokumentów zaczęto również organizować dla nich darmowe kursy języka polskiego, zarówno ogólnego jak i specjalistycznego. M ożliwość udziału w bezpłatnych zajęciach podwyższających kompetencje językowe przyciąga niemałe grono zainteresowanych obywateli państw zza naszej wschodniej granicy. Aby uzyskać prawo wykonywania zawodu w Polsce, cudzoziemcy spoza Unii Europejskiej są zobowiązani nie tylko przejść pomyślnie długie i skomplikowane procedury mające na celu nostryfikację dyplomu. M uszą również uzyskać status imigracyjny oraz zdać egzamin z języka polskiego organizowany przez Naczelną Izbę Lekarską. Konieczne jest także odbycie trzynastomiesięcznego stażu zawodowego.

Wzrost znaczenia polskiego rynku pracy na arenie międzynarodowej spowodował, że początek XXI wieku przyniósł większy niż do tej pory wzrost zainteresowania nauczaniem języka polskiego do celów zawodowych i specjalistycznych. Sytuacja ta skłania teoretyków i praktyków nauczania języka polskiego jako obcego do refleksji glottodydaktycznej i stawia badaczy przed nowymi wyzwaniami metodycznymi oraz teoriotwórczymi. Współcześnie - jak podkreśla Sowa - nie da się już oddzielić kształcenia językowego od potrzeb i wymagań rynku pracy (por. Sowa, 2013: 5). Potwierdzeniem tej tezy jest Rozporzqdzenie M EN w sprawie podstawy programowej kształcenia w zaw odach²

${ }^{1}$ https:// www.rp.pl/Rynek-pracy/310229902-Ostatnia-szansa-na-lekarzy-ze-Wschodu.html [DW 24.04.2021].

2 http://isap.sejm.gov.pl/isap.nsf/download.xsp/WDU20120000184/0/D20120184.pdf [DW13.04.2021]. 
Miejsce sprawności językowych na zajęciach języka specjalistycznego...

oraz - co jest istotne w kontekście niniejszego tekstu - Ustawa o zawodach lekarza i lekarza dentysty ${ }^{3}$.

Jeszcze do niedawna nauczaniem medycznej odmiany polszczyzny zajmowały się głównie ośrodki akademickie. Choć do tej pory nauczanie języka polskiego do celów medycznych nie doczekało się jeszcze naukowego opracowania, rozwiązania praktyczne w postaci licznych materiałów glottodydaktycznych wyglądają całkiem obiecująco ${ }^{4}$.

\section{Przedmiot i cel badawczy}

Przedmiotem refleksji niniejszego tekstu są szeroko pojęte potrzeby językowe cudzoziemców, którzy zamierzają podjąć pracę w polskim sektorze ochrony zdrowia. Szczególne miejsce w prowadzonych przeze mnie badaniach nad nauczaniem polskiego języka medycznego zajmują zaś sprawności językowe.

Głównym celem artykułu jest przedstawienie wyników dwóch ankiet. Pierwsza z nich obejmowała analizę potrzeb uczestników kursu języka specjalistycznego, druga z kolei dotyczyła oceny przebiegu całego kursu (10 zajęć w wymiarze 90 minut).

W badaniach zastosowano dwa kwestionariusze - pierwszy składał się z siedmiu otwartych pytań, drugi zaś z sześciu. Ankiety zostały przeprowadzone w odstępie trzech miesięcy - w listopadzie 2020 roku (przed rozpoczęciem kursu) oraz w styczniu 2021 roku, po zakończeniu zajęć i miały charakter diagnostyczno-opisowy. Udzielone odpowiedzi nie podlegały ocenie w kategoriach poprawna / niepoprawna.

W pierwszym badaniu wzięło udział łącznie 38 osób: 19 z Białorusi, 17 z Ukrainy i 2 z Rosji. Wielkość próby ankiety końcowej to 33 wypełnione kwestionariusze. Najmłodsza osoba miała 22 lata, a najstarsza biorąca udział w ankiecie była w wieku 60 lat. Wszystkie miały wyższe wykształcenie medyczne, a wśród najczęściej wymienianych specjalizacji wskazywano neurologię, pediatrię, dermatologię, ginekologię i położnictwo, psychologię, psychiatrię, kardiologię oraz stomatologię. Każdy z respondentów miał już doświadczenie zawodowe (od kilku miesięcy do 35 lat) zdobyte podczas pracy w swoim kraju, we własnym środowisku językowym. Wieloletnia praktyka uczestników w wykonywanym zawodzie pozwoliła wyeliminować potrzeby wyobrażeniowe dotyczące nauczania języka specjalistycznego.

\footnotetext{
${ }^{3}$ http://isap.sejm.gov.pl/isap.nsf/download.xsp/WDU19970280152/0/D19970152.pdf [DW13.04.2021].

${ }^{4}$ Zob. Oczko (w druku).
} 


\section{Analiza potrzeb i jej miejsce w planowaniu kursu specjalistycznego}

Temat analizy potrzeb w kształceniu zawodowym był już podejmowany przez badaczy (por. Kubicka 2010; Lesiak-Bielawa 2013; Gajewska, Sowa 2010, 2014; Kiefer, Szerszeń 2014; Sowa 2016; Sendur 2018). Zdaniem Gajewskiej i Sowy (2010: 248):

Nauczanie języka dla celów zawodowych bardziej niż jakiekolwiek inne wykorzystuje metody analizy potrzeb do konstruowania programów nauczania, ponieważ celem miało być przyswojenie najszybciej jak to możliwe wiedzy, umiejętności językowych i właściwych zachowań w ograniczonym zakresie wystarczających, aby uczeń był w stanie stawiać czoła sytuacjom, w których się znajdzie w swoim życiu zawodowym.

Analizę potrzeb definiuje się jako empiryczny proces identyfikacji sytuacji zawodowych użycia języka. Stanowi ona podstawę indywidualnego i instrumentalnego planowania kursów językowych oraz źródło informacji umożliwiających interpretację problemów i oczekiwań uczestników wobec zajęć językowych (Kiefer, Szerszeń, 2015; Niemiec, 2016: 71). Początkowo analiza potrzeb była rozumiana jako prosta procedura, której celem było oszacowanie przed kursem docelowej sytuacji komunikacyjnej. Ponadto obejmowała ocenę punktu startowego oraz rozwiązania dydaktyczne, które pozwalają osiągnąć zamierzony cel (por. Krajka, 2015: 222). Współcześnie termin ten jest rozumiany znacznie szerzej. Według najnowszych badań nad definicją analizy potrzeb prowadzonych przez Dudley-Evansa i St. Johna (2009), pojęcie to należy rozumieć jako zbiór połączonych ze sobą komponentów, które dostarczają informacji na temat uczącego się: jego umiejętność językowych w zakresie komunikacji zawodowej, doświadczenia w nauce języków, preferowanych technik uczenia się oraz brakach językowych. Analiza potrzeb powinna obejmować także dane dotyczące powodów udziału w zajęciach i poziomu motywacji do nauki. Istotne są także informacje na temat obiektywnych potrzeb językowokomunikacyjnych wynikających ze specyfiki środowiska pracy i obowiązków zawodowych (Dudley-Evans, St. John, 2009: 125; za Lesiak-Bielawa, 2013: 102-103). Sendur podkreśla, iż przeprowadzenie analizy potrzeb powinno pokazać, które sprawności mają istotne znaczenie w komunikacji w określonych sytuacjach zawodowych oraz jakie funkcje językowe i jaka terminologia są niezbędne dla realnego wykonywania zadań zawodowych z użyciem języka obcego (Sendur, 2020: 50; por. Gajewska, Sendur, 2015).

Do najczęściej stosowanych metod badawczych służących pozyskiwaniu danych na temat oczekiwań oraz potrzeb uczniów należą: wywiad, ankieta, obserwacja, testy plasujące i diagnostyczne oraz różnego rodzaju formy oceniania 
Miejsce sprawności językowych na zajęciach języka specjalistycznego...

alternatywnego pozwalajace na opisanie kompetencji ucznia (por. Komorowska 2002). Przeprowadzenie ankiety czy też wywiadu w celu zdobycia informacji na temat potrzeb odbiorców kursu jest niezwykle pomocne, zwłaszcza w sytuacji, gdy zajęcia (lub blok lekcji) adresowane są do konkretnych odbiorców, czas trwania szkolenia jest ograniczony, a na rynku brakuje gotowych materiałów dydaktycznych, które można wykorzystać w pracy z daną grupą. W tej sytuacji lektor jest zmuszony do przygotowania całego programu. Choć istnieje ryzyko, że prowadzący skupi się bardziej w takiej sytuacji na tym, czego uczyć, a nie jak uczyć, nie zmienia to faktu, że analiza potrzeb powinna być stałym elementem planowania kursów języka specjalistycznego.

Niezbędną fazą kursu języka specjalistycznego jest także ewaluacja, która może być przeprowadzana zarówno w trakcie jego trwania, np. w celu jego kształtowania i dopasowywania na bieżąco, jak i po zakończeniu. Jej celem jest przede wszystkim ocena efektywności procesu nauczania (por. LesiakBielawa 2013: 108). Ewaluacji mogą zostać poddane takie elementy jak: wykorzystywany na zajęciach materiał glottodydaktyczny, przydatność kursu w zakresie komunikacji specjalistycznej w życiu zawodowym czy efektywność podejmowanych w procesie uczenia (się) działań dydaktycznych.

\section{Oczekiwania uczestników wobec kursu - omówienie ankiety}

\subsection{Poziom znajomości języka ogólnego i specjalistycznego kursantów}

Pierwsza część ankiety poprzedzającej kurs obejmowała cztery pytania faktograficzne dotyczące płci, wieku, wykształcenia oraz kraju pochodzenia. Udzielone na nie odpowiedzi na pozwoliły dokonać charakterystyki grupy badawczej. Druga część formularza dotyczyła poziomu znajomości języka ogólnego oraz specjalistycznego. Na pytanie o doświadczenia w nauce języka ogólnego oraz formy jego nauki ankietowani najczęściej wskazywali prywatne korepetycje oraz udział w kursach językowych organizowanych przez zagraniczne szkoły językowe i ośrodki polonijne. Respondenci deklarowali znajomość języka polskiego ogólnego w mowie i piśmie na różnych poziomach, od $\mathrm{A} 2$ do $\mathrm{Cl}^{5}$.

Natomiast, co warto podkreślić, nikt ze słuchaczy nie uczestniczył wcześniej w kursie języka specjalistycznego. Na pytanie o znajomość medycznej odmiany polszczyzny 47\% ankietowanych (tj. 18 osób) zaznaczyło, że potrafi przeprowadzić podstawowy wywiad internistyczny z pacjentem, dziewiętnaście osób (tj. 52\%) zadeklarowało umiejętność przeczytania i zrozumienia nieskomplikowanego tekstu medycznego (w odpowiedziach częściej pojawiały

${ }^{5}$ Dane te zostały zweryfikowane na teście diagnostycznym. 
się wzmianki o krótkich epikryzach oraz tekstach popularnonaukowych np. na portalach medycznych niż o tekstach naukowych, jak np. artykuły akademickie, studium przypadku). Natomiast tylko dziewięć osób - czyli w przybliżeniu $24 \%$ przyszłych kursantów - oznajmiło, że jest w stanie napisać samodzielnie skierowanie na badania.

\subsection{Oczekiwania wobec kursu}

W trzeciej części kwestionariusza znalazło się pytanie o twarte dotyczące oczekiwań wobec kursu, jego przebiegu oraz celu do osiągnięcia po zakończeniu. Respondenci mogli udzielić więcej niż jednej odpowiedzi. Najczęściej powtarzały się następujące z nich:

- przygotowanie do płynnej, poprawnej fonetycznie i gramatycznie komunikacji w środowisku zawodowym - w rozmowie z pacjentem oraz innymi lekarzami, ale również w trakcie wystąpienia na konferencji ( 25 osób, tj. 65\%);

- poznanie polskiej terminologii medycznej (20 osób, tj. 52\%);

- przygotowanie do egzaminu z języka polskiego organizowanego przez Naczelną Izbę Lekarską oraz do testów będących częścią procedury nostryfikacji dyplomu (15 osób, tj. 39\%);

- powtórzenie wiadomości z zakresu polskiej gramatyki oraz podniesienie kompetencji w języku ogólnym (13 osób, tj. 34\%);

- zapoznanie się z polską dokumentacją medyczną (11 osób, tj. 29\%);

- zdobycie wiedzy na temat funkcjonowania polskiej służby zdrowia (6 osób, tj. 15\%);

- pozyskanie informacji na temat podręczników i materiałów specjalistycznych, z których można uczyć się samodzielnie (6 osób, tj. 15\%);

- rozwinięcie sprawności czytania, aby w przyszłości móc czytać literaturę specjalistyczną (4 osoby, tj. 15\%);

- nabycie umiejętności redagowania tekstów naukowych (4 osoby, tj. 10\%);

- zdobycie wiedzy specjalistycznej z zakresu neurologii oraz ginekologii (4 osoby, tj. 10\%);

- uzyskanie wiedzy na temat zatrudniania w sektorze zdrowotnym na polskim rynku pracy (procedury, potrzebne dokumenty, wynagrodzenie) (3 osoby, tj. 7\%);

- pozyskanie wiedzy i umiejętności pozwalających zachować socjokulturowy wymiar komunikacji w polskim środowisku medycznym (2 osoby, tj. 5\%).

W pojedynczych wypowiedziach pojawiły się: pragnienie przezwyciężenia lęku przed mówieniem w języku obcym, chęć doskonalenia poziomu znajomości 
Miejsce sprawności językowych na zajęciach języka specjalistycznego...

języka ogólnego, możliwość rozmowy w języku polskim, ponieważ na co dzień jest to niemożliwe. Jedna z osób uczestniczących w kursie była z zawodu tłumaczem, zajmowała się przekładem ukraińskich tekstów medycznych na język angielski. Uczestnictwo w kursie miało pomóc jej przede wszystkim w zapoznaniu się z polską dokumentacją medyczną.

Respondenci zgodnie podkreślali, iż udział w kursie podniesie ich kwalifikacje językowe, dzięki czemu będą mieli większą szansę na znalezienie pracy w polskich placówkach zdrowia.

\section{Sprawności receptywne i produktywne a świadomość językowa uczestników kursu języka specjalistycznego}

We współczesnym podejściu do dydaktyki nauczania języków podkreśla się, że wyizolowanie czterech sprawności i uczenie ich oddzielnie nie jest zabiegiem naturalnym (poza wyjątkowymi sytuacjami, kiedy jest to wręcz wskazane, np. w pracy ze studentem o określonych dysfunkcjach czy zaburzeniach) (por. Chłopek 2016: 4).

Badania nad językami specjalistycznymi w Polsce sięgają lat siedemdziesiątych ubiegłego wieku. Przez wiele lat podejmowano się niełatwego zadania zdefiniowania ich zakresu znaczenia. Najwięcej miejsca w opisie tychże języków poświęcano roli terminologii specjalistycznej, znacznie mniej koncentrując się na sprawnościach receptywnych i produktywnych. Dopiero od niedawna stawia się je w centrum zainteresowania (por. Gajewska, Sowa, 2014: 30). Jednym z powodów, dla którego w ankiecie podjęto zagadnienie rozwijania sprawności receptywnych i produktywnych był fakt, iż w nauczaniu języka do celów zawodowych - tak jak w nauczaniu języka ogólnego - istotne jest osiągnięcie umiejętności naturalnego iskutecznego porozumiewania się w obrębie czterech sprawności językowych (por. Zawadzka, 2004: 140).

Drugim powodem, dla którego podjęto próbę zbadania świadomości językowej uczestników kursu języka specjalistycznego pod kątem konieczności rozwijania sprawności językowych, jest egzamin z języka polskiego jako obcego organizowany przez Naczelną Izbę Lekarską. Obecnie jest to jedyny egzamin specjalistyczny z zakresu medycznej odmiany polszczyzny, a jego zdanie jest warunkiem koniecznym, aby ubiegać się o prawo wykonywania zawodu lekarza lub lekarza dentysty w Polsce. Według Rozporzqdzenia M inistra Zdrowia w sprawie zakresu znajomości języka polskiego w mowie i piśmie, niezbędnej do wykonywania zawodu lekarza, lekarza dentysty na terytorium Rzeczypospolitej Polskiej z dnia 29 czerwca 2009 roku na cudzoziemców nakłada

${ }^{6}$ W rozporządzeniu M inistra Zdrowia w sprawie w sprawie egzaminu ze znajomości języka polskiego niezbędnej do wykonywania zawodu lekarza i lekarza stomatologa 
się obowiązek opanowania znajomości języka polskiego w odmianie ustnej i pisemnej w stopniu umożliwiającym:

- posługiwanie się w mowie i piśmie bogatym zasobem terminologii medycznej;

- rozumienie tekstu pisanego, korzystanie ze specjalistycznej literatury oraz dokumentów prawnych normujących wykonywanie zawodu lekarza lub lekarza dentysty w Polsce;

- sprawne komunikowanie się z pacjentami i pracownikami sektora medycznego;

- czytelne odręczne prowadzenie dokumentacji medycznej i przygotowywanie poprawnych pod względem gramatycznym i ortograficznym tekstów różnego rodzaju.

(Dziennik Ustaw 2009 nr 108 poz. 908) ${ }^{7}$

Wszyscy lekarze i lekarze dentyści, którzy studiowali w języku innym niż polski, a chcieliby wykonywać swój zawód w Polsce, muszą wykazać się umiejętnością rozumienia tekstów słuchanych i pisanych oraz opanowaniem sprawności mówienia i pisania. Posiadanie wyżej wymienionych kompetencji weryfikowane jest przez komisję do poświadczania znajomości języka polskiego w Naczelnej Izbie Lekarskiej. Zgodnie z Rozporzqdzeniem Ministra Zdrowia (Dziennik Ustaw 2009 nr 108 poz. 908) egzamin składa się z czterech części, zwanych sprawdzianami:

- sprawdzian pisemny - dyktando z nośnika elektronicznego ${ }^{8}$;

- sprawdzian testowy - rozumienie tekstu słuchanego z nośnika elektronicznego ${ }^{9}$;

(Dz. U. Nr 205, poz. 1740) z 27 listopada 2002 roku wymieniono konieczność opanowania umiejętności rozumienia tekstu pisanego, porozumienia się z pacjentami, lekarzami i pozostałymi pracownikami służby zdrowia oraz umiejętności pisemnego prowadzenia dokumentacji medycznej. Dopiero w rozporządzeniu z 23 lipca 2007 roku i obowiązującym do dziś rozporządzeniu z 29 czerwca 2009 roku dodano wymóg stosowania w mowie i piśmie prawidłowej terminologii medycznej.

7 https:// isap.sejm.gov.pl/isap.nsf/download.xsp/WDU20091080908/0/D20090908.pdf [DW 13.04.2021].

${ }^{8}$ Celem przeprowadzenia części A jest sprawdzenie umiejętności pisania ze słuchu w języku polskim oraz zweryfikowanie znajomości polskiej ortografii. Komisja ocenia czytelność pisma, kompletność tekstu oraz ortografię. https://nil.org.pl/dla-lekarzy/ mlodzi-lekarze/4282-egzaminy-z-jezyka-polskiego [DW 12.04.2021].

${ }^{9}$ Sprawdzian testowy w części B polega na wysłuchaniu tekstu z nośnika elektronicznego i udzieleniu odpowiedzi na 10 pytań testowych dotyczących treści jego treści. https://nil.org.pl/dla-lekarzy/mlodzi-lekarze/4282-egzaminy-z-jezyka-polskiego [DW12.04.2021]. 
Miejsce sprawności językowych na zajęciach języka specjalistycznego...

- $\quad$ sprawdzian ustny - głośne czytanie i rozumienie tekstu ${ }^{10}$;

- sprawdzian praktyczny - przeprowadzenie symulowanego wywiadu lekarskiego ${ }^{11}$.

Mając na uwadze formę egzaminu z języka polskiego organizowanego przez Naczelną Izbę Lekarską, jedno z pytań w ankiecie dotyczyło miejsca sprawności receptywnych i produktywnych w nauczaniu medycznej odmiany polszczyzny ${ }^{12}$. W pierwszej kolejności respondenci mieli ocenić w skali od 1 do 4, które sprawności językowe ich zdaniem są najbardziej pożądane (ocena 1), a które najmniej potrzebne (ocena 4) w zawodzie lekarza (lekarza-stomatologa). Następnie osoby musiały uzasadnić przyjętą przez siebie hierarchię.

Zgodnie z przewidywaniami, które potwierdzają również przedstawione powyżej oczekiwania wobec kursu językowego, ankietowani za najbardziej pożądaną i niezbędną w zawodzie lekarza uznali sprawność mówienia (68\%, czyli 26 osób). Jako drugie w hierarchii najczęściej umieszczano rozumienie tekstów słuchanych (42\%, tj. 16 osób). Na trzecim miejscu znalazło się pisanie (36\%, tj. 14 osób), natomiast rozumienie tekstów pisanych uplasowało się na ostatnim, czwartym miejscu (50\%, tj. 18 osób).

Respondenci tak oto uzasadnili swój wybór ${ }^{13}$ :

M oim zdaniem wszystkie umiejętności językowe sq potrzebne w pracy lekarza. Mówienie - to pierwsza umiejętność, z którq spotyka się pacjent w gabinecie lekarskim. Dalej lekarz słucha pacjenta, odpowiada na zapytania, wypisuje recepty, i oczywiście że wykorzystuje czytanie w swoim kierunku.

[respondent 3]

${ }^{10}$ W części ustnej (C) zdający ma za zadanie głośno przeczytać tekst drukowany (standardowa strona maszynopisu), a następnie udzielić odpowiedzi na 5 pytań dotyczących jego treści. Komisja sprawdza umiejętności głośnego czytania w języku polskim oraz rozumienie samego tekstu. Przy ocenie brana jest pod uwagę umiejętność czytania oraz poprawność udzielonych odpowiedzi. https://nil.org.pl/dla-lekarzy/mlodzilekarze/4282-egzaminy-z-jezyka-polskiego [DW12.04.2021].

${ }^{11}$ Egzamin kończy część praktyczna (D), której celem jest sprawdzenie umiejętności poprawnego formułowania pytań i wypowiedzi w języku polskim. Zdający zostaje postawiony w medycznej sytuacji komunikacyjnej lekarz - pacjent i musi przeprowadzić stymulowany wywiad anamnestyczny na podstawie dwóch wylosowanych problemów medycznych. Ocenie poddane są: poprawność formułowania pytań i wypowiedzi, poprawność wymowy - poprawność formułowania zaleceń oraz zasób słownictwa specjalistycznego. https://nil.org.pl/dlalekarzy/mlodzi-lekarze/4282-egzaminy-z-jezyka-polskiego [DW 12.04.2021].

${ }^{12}$ Więcej na temat koncepcji rozwijania sprawności językowych w nauczaniu polskiego języka medycznego można znaleźć w pracach Oczko (2020a; 2020b).

${ }^{13}$ Zachowuję oryginalną pisownię wypowiedzi respondentów. 
Aby móc porozumiewać się z pacjentem, lekarz musi dobrze mówić i rozumieć mowę przez ucho.

[respondent 8]

Słuchanie i mówienie sq pod n. 1, bo pozwala ocenić rodzaj i rozmiar problemu i potem odnieść do pacjenta, co ma robić dla swego zdrowia. Tłumacz Google pomoże pisać i czytać.

[respondent 14]

M yślę tak, bo z pacjentem trzeba dużo mówić, trzeba go słuchać, już potem coś pisać. [respondent 22]

Mówienie jest bardzo ważne w komunikacji z pacjentami, pisanie tez jest ważne w prowadzeniu dokumentacji.

[respondent 23]

Pojawiły się też głosy kwestionujące hierarchiczny podział sprawności w nauczaniu języka specjalistycznego. Przykładowo, ankietowani stwierdzili:

Naprawdę to uważam, że wszystko jest ważne i potrzebne dla lekarza.

[respondent 17]

M oim zdaniem wszystkie punkty sq potrzebne w zawodzie lekarza na równi;bez słuchania nie ma mówienia, bez czytania i pisania nie ma pamięci i nawyków.

[respondent 21]

Ogólne spojrzenie na pozyskane dane pozwala wywnioskować, iż respondentom bliżzze jest rozumienie nauczanego przedmiotu jako języka praktyki medycznej (języka klinicznego) - pojęcia używanego w związku z bezpośrednią opieką lekarską, kontaktem z ludźmi chorymi - niż jako języka nauki medycznej, będącego systemem uznanych twierdzeń ogólnych, wyrażających wiedzę przedmiotową i metodyczną (por. Doroszewski 2010: 299)14.

\section{Omówienie ankiety oceniającej zajęcia}

Po zakończeniu kursu uczestnicy zostali poproszeni o wypełnienie ankiety podsumowującej przebieg zajęć. Formularz składał się z sześciu opisowych pytań, które dotyczyły:

- oceny własnych postępów w nauce,

- atrakcyjności zajęć (tempa przebiegu lekcji, klarowności wyjaśnieńlektora),

- przydatności kursu w rozwoju zawodowym,

${ }^{14}$ Doroszewski posługuje się również terminem komunikacja medyczna (por. Doroszewski 2007: 43). 
Miejsce sprawności językowych na zajęciach języka specjalistycznego...

- materiału, na który poświęcono zbyt wiele czasu,

- materiału, na który poświęcono za mało czasu,

- materiału, który powinien zostać w prowadzony na kursach w przyszłości.

Szesnaścioro ankietowanych (tj. 48\%) oceniło swoje postępy w nauce jako dobre, jako bardzo dobre dziewięć osób (tj. 27\%). Sześcioro respondentów (tj. 18\%) było zdania, że ich znajomość języka polepszyła się w stopniu dostatecznym, natomiast dwoje ankietowanych (tj. 6\%) nie udzieliło odpowiedzi.

Same zajęcia zostały ocenione jako bardzo dobre: żadnych zastrzeżeń nie budziły zarówno tempo lekcji, klarowność wyjaśnień lektora, jak i dobór materiału czy liczba i charakter prac domowych. Za największy walor zajęć uznano wykorzystanie nagrań audiowizualnych z udziałem lekarzy różnych specjalności. Ponadto wysoko zostały ocenione ćwiczenia typu case study, w których uczestnicy w zespołach trzy-, czteroosobowych mieli opracować konkretny przypadek, a następnie zaprezentować go na forum. Za interesujące uznano również ćwiczenia oparte na autentycznej dokumentacji medycznej takiej jak: wyniki badań, karta operacji, wypis ze szpitala, opis operacji ${ }^{15}$, zwrócono jednak uwagę na ich niedostateczną liczbę. Respondenci uważali także, że czas trwania całego kursu był zbyt krótki, zgodnie przyznali też (93\%, tj. 31 osób), iż jest on bardzo przydatny osobom spoza Unii Europejskiej, które szukają zatrudnienia w polskiej służbie zdrowia. Osoby biorące udział w badaniu uznały, że największym minusem zajęć zorganizowanych w trybie online był brak możliwości prowadzenia swobodnych rozmów i ćwiczenia dialogów (7 osób, tj. 21\%). Sprawnością, której zdaniem respondentów lektor poświęcał najmniej czasu, było pisanie (10 osób, tj. 30\%).

Co ciekawe, w ankiecie przeprowadzonej przed kursem, poznanie i poszerzenie znajomości polskiej terminologii medycznej było jedną z trzech najczęściej wskazywanych potrzeb uczących się. W formularzu końcowym ankietowani wskazali, że w przyszłości na zajęciach powinna być wprowadzona jeszcze większa ilość słownictwa specjalistycznego. Dlatego może dziwić fakt, że aż 14 osób (tj. 42\%) było zdania, że rozwijaniu sprawności rozumienia tekstów pisanych poświęcano za dużo czasu. Trudno przecież wyobrazić sobie lepszą możliwość prezentowania leksyki specjalistycznej niż właśnie w tekście. Praca ze słownikiem jest oczywiście jak najbardziej wskazana, ale niewystarczająca w nauce języka specjalistycznego. Smuk zauważa (2007: 66): „język specjalistyczny (w tym przypadku medyczny) posiada szereg atrybutów, a jego specyficzny charakter

${ }^{15}$ Dziewięcioro kursantów, będących na bardzo wysokim poziomie języka ogólnego pracowało dodatkowo z tekstami naukowymi. Ta forma pracy również została oceniona wysoko. 
nie ogranicza się tylko i wyłącznie do obecności terminów specjalistycznych. Jego podstawowym wyróżnikiem jest realizacja pisana, a co za tym idzie, bardziej rygorystyczne przestrzeganie norm językowych, większa spójność i zwartość". Podobna niekonsekwencja pojawiła się w ocenie rozwijania na kursie sprawności mówienia, która przez wszystkich została wskazana jako najbardziej pożądana w zawodzie lekarza, a aż 65\% badanych napisało, że oczekuje od zajęć rozwinięcia kompetencji sprawnego ustnego komunikowania w środowisku zawodowym. M imo to dwanaścioro ankietowanych (tj. 36\%) wskazało, że sprawności tej poświęcano za dużo czasu. Cztery osoby (tj. 10\%) były zdania, że wszystkim sprawnościom językowym (mówieniu, słuchaniu, czytaniu, pisaniu) i podsystemom języka (gramatyce, słownictwu medycznemu) poświęcano za dużo czasu. Tyle samo osób twierdziło, że na rozwijanie wszystkich tych sprawności oraz przeznaczano za mało czasu.

\section{Implikacje dla glottodydaktyki specjalistycznej}

Zagadnienie rozwijania sprawności językowych w nauczaniu języków specjalistycznych w czasie nauki zdalnej wykraczają poza zjawiska przedstawione w niniejszym tekście. Przeprowadzona analiza potrzeb oraz ankieta ewaluacyjna przebiegu kursu pozwalają jedynie na wnioski o ogólnym charakterze.

W odpowiedziach na pytanie o to, jakie treści powinny znaleźć się w kursie językowym organizowanym w przyszłości, uczestnicy kursu zwrócili uwagę na kilka kwestii poza powyżej omówionymi. Po pierwsze, według 11 osób (34\%) należy zadbać o przygotowanie i udostępnienie studentom przed rozpoczęciem kursu szczegółowego harmonogramu zajęć z uwzględnieniem zakresu tematycznego oraz zagadnień gramatycznych. Ankietowani biorący udział w badaniu uzasadniali, że w ten sposób będą wiedzieli, czego spodziewać się na zajęciach i w jaki sposób się do nich przygotować. Respondenci zwrócili także uwagę na mały odstęp czasowy między zajęciami. Ich zdaniem lekcje odbywające się według planu: poniedziałek i środa lub wtorek i czwartek albo środa i piątek są bardzo niekorzystnym rozwiązaniem, jeden dzień przerwy jest bowiem niewystarczający, aby powtórzyć materiał, odrobić pracę domową oraz przygotować się do nowej lekcji, zwłaszcza że wszyscy uczestnicy kursu byli osobami pracującymi.

Jeśli chodzi o samą zdalną formę zajęć, ku zaskoczeniu autorki tekstu, ankietowani nie mieli uwag krytycznych. Mimo pojedynczych głosów wskazujących np. na brak możliwości swobodnego wypowiadania się, nieumiejętność włączenia się do rozmowy (wyłączone kamery uniemożliwiły obserwację innych osób), ostatecznie zdalna forma zajęć spotkała się zoceną pozytywną. Respondenci nie odczuli, aby któraś ze sprawności językowych została całkowicie pominięta przez lektora bądź nie można było jej rozwinąć. 
Miejsce sprawności językowych na zajęciach języka specjalistycznego...

Chciałabym także zwrócić uwagę na aspekt kompetencji merytorycznej w nauczaniu języka specjalistycznego. M imo, że tylko niewielka grupa osób wypełniających ankietę oczekiwała, że zdobędzie specjalistyczną wiedzę z zakresu konkretnej dziedziny medycyny, to trudno oprzeć się wrażeniu, że w przekonaniu uczestników kursu lektor uczy nie tylko języka, ale również przekazuje wiedzę specjalistyczną. Z tego powodu ważne jest uświadomienie słuchaczom na samym początku zajęć, że nauczyciel jest specjalistą przede wszystkim w kształceniu językowym. Przekazywanie wiedzy naukowej z zakresu medycyny wykracza dalece poza jego kompetencje. Wprawdzie wskazane jest, aby osoba prowadząca lekcje wykazywała zainteresowanie przedmiotem oraz posiadała podstawową znajomość z obszaru konkretnej dziedziny, ale nie musi być wykładowcą tej dyscypliny. Jak podkreślają Gajewska i Sowa, sytuacja, w której uczniowie występują w roli ekspertów w stosunku do nauczyciela-laika, jest w glottodydaktyce specjalistycznej bardzo częsta (por. Gajewska, Sowa, 2014: 112).

Określając oczekiwania wobec kursu językowego, ankietowani wymienili potrzebę uzyskania wiedzy na temat procedury zatrudniania w sektorze zdrowotnym na polskim rynku pracy (przebieg nostryfikacji dyplomu, minimalne wynagrodzenie dla lekarzy i pielęgniarek, czas oczekiwania na konkretne dokumenty). Podobnie jak w kwestii wiedzy z zakresu medycyny, tak i tutaj mogą pojawić się kwestie, które będą wykraczały poza kompetencje lektora. Nauczyciel/lektor jest więc dla kursantów/słuchaczy osobą, która powinna posiadać wiedzę na każdy temat, aby przygotować do wykonywania zawodu nie tylko w zakresie kompetencji językowej, ale również wiedzy specjalistycznej oraz zawodowej. Zapewne taka postawa wynika z faktu, że to lektor jest osobą „pierwszego kontaktu w języku obcym”, z którą uczeń spotyka się najczęściej i do której ma największe zaufanie.

Choć w ankiecie wzięły udział osoby z Białorusi, Rosji oraz Ukrainy, krajów bardzo zbliżonych kulturowo do Polski, dwoje respondentów zwróciło uwagę na potrzebę rozwijania kompetencji socjolingwistycznej i socjokulturowej, które pozwalają zachować socjokulturowy wymiar komunikacji. Jak wynika z przeprowadzonej analizy potrzeb, zagadnienia kompetencji socjolingwistycznej, ale nie tylko, bo również socjokulturowej i realioznawczej, powinny znaleźć stałe miejsce w nauczaniu polskiego języka medycznego ${ }^{16}$. Jak podkreśla Wojnicki:

Reguły socjolingwistyczne [...] różnią się bardzo w zależności od kraju; rola ich wydatnie wzrasta w komunikacji bezpośredniej, «twarzą w twarz» bądź listowej, i nie sposób opracować dziś poważnego kursu językowego przygotowującego do takiej komunikacji bez ich uwzględnienia. Jest to zagadnienie dużej

${ }^{16}$ Zob. Oczko (w druku). 
wagi również w nauczaniu języków obcych do celów zawodowych. W wielu krajach istnieją bardzo sztywne reguły formułowania korespondencji służbowej, handlowej itp., i naruszenie tych reguł może mieć istotny wpływ na realizację celów merytorycznych.

(Wojnicki, 1991: 68)

W mojej ocenie, mimo prowadzonych obecnie dość licznie kursów polskiego języka dla lekarzy, nadal brakuje publikacji naukowych na temat organizacji zajęć języka specjalistycznego (medycznego) oraz potrzeb językowych ich uczestników. Zaprezentowane w artykule wyniki obejmują niewielką grupę badanych, jednak wskazują na aspekty ważne dla glottodydaktyki polonistycznej, w obrębie której do tej pory zajmowano się głównie nauczaniem polskiego języka medycznego na studiach anglojęzycznych.

\section{BIBLIOGRAFIA}

Chłopek Z. (2016), Rozwijanie sprawności receptywnych w języku obcym. „Język Obce w Szkole", nr 1, s. 4-10.

Doroszewski J. (2010), Język nauki i praktyki medycznej, (w:) M ilewska-Stawina M., Rogowska-Cybulska E. (red.), Polskie języki. 0 językach zawodowych i środowiskowych. Gdańsk: Wydawnictwo Uniwersytetu Gdańskiego, s. 299-319.

Doroszewski J. (2010), Komunikacja personelu medycznego zpacjentem aspekt językowy, psychologiczny i etyczny, (w:) Krauz M., Ozóg K. (red.), Kultura zachowań językowych Polaków. Materiały VIII Forum Kultury Słowa. Rzeszów: Wydawnictwo U niwersytetu Rzeszowskiego, s. 139-146. ESOKJ (2003), Europejski system opisu kształcenia językowego: uczenie się, nauczanie, ocenianie. Warszawa: CODN.

Gajewska E., Sendur A. (2015), Ocenianie w nauczaniu języków obcych zorien-

towanym na cele ogólne a ocenianie w nauczaniu zorientowanym na cele zawodowe. "Języki Obce w Szkole", nr 3, s. 49-53.

Gajewska E., Sowa M . (2010), M etodologia konstrukcji kursu języka obcego dla potrzeb zawodowych. „Neofilolog”, nr 35, s. 243-253.

Gajewska E., Sowa M . (2014), LSP, FOS, Fachsprache... Dydaktyka języków specjalistycznych. Lublin: Werset.

Gajewska E., Sowa M . (2014), Sposoby kształcenia nauczycieli języków specjalistycznych: od rzeczywistości edukacyjnej do rozwiq̨zań systemowych. "Neofilolog" nr 44/2, s. 221-235.

Kiefer K-H., Szerszeń P. (2014), Badania potrzeb językowo-komunikacyjnych na przykładzie wybranych obszarów zawodowych w polsko-niemieckim kontekście gospodarczym, (w:) Sowa M., M ocarz-Kleindienst M., Czyżewska 
Miejsce sprawności językowych na zajęciach języka specjalistycznego...

U. (red.) Nauczanie języków obcych na potrzeby rynku pracy. Lublin: Wydawnictwo KUL, s. 129-142.

Komorowska H. (2002), Sprawdzanie umiejętności w nauce języka obcego: kontrola, ocena, testowanie. Warszawa: Fraszka Edukacyjna.

Krajka J. (2015), Analiza potrzeb w planowaniu kursów językowych do celów zawodowych - o roli technologii społeczeństwa informacyjnego, (w:) Sowa M., M ocarz-Kleindienst M., Czyżewska U. (red.) Nauczanie języków obcych na potrzeby rynku pracy. Lublin: Wydawnictwo KUL, s. 221-237.

Kubicka M . (2010), Nauczanie i rozwijanie sprawności komunikacyjnych w obcojęzycznym dyskursie specjalistycznym. Potrzeby, wyzwania, innowacje. „Neofilolog", nr 35, s. 117-128.

Lesiak-Bielawa E.D. (2013), Rola analizy potrzeb i ewaluacji kursu w nauczaniu języka specjalistycznego. „Neofilolog”, nr 41/2, s. 99-112.

Niemiec J. (2016), Needs analysis for a specialized learner population: a case study of learners from Medical College. „Państwo i Społeczeństwo”, nr 3, s. 71-84. Oczko P. (2020a), Koncepcje rozwijania sprawności językowych w nauczaniu polskiego języka medycznego, (w:) Grygiel M., Rzepecka M. (red.), Komunikacja specjalistyczna w edukacji, translatoryce i językoznawstwie. Rzeszów: Wydawnictwo Uniwersytetu Rzeszowskiego, t. 4, s. 32-41.

Oczko P. (2020b), Techniki rozwijania sprawności słuchania i mówienia w podręcznikach do nauczania polskiego języka medycznego. „Acta Universitatis Lodziensis. Kształcenie Polonistyczne Cudzoziemców", nr 27, s. 435-450.

Oczko P. (w druku), Język medycyny (medyczny) - dyskusja nad definicja.

Oczko P. (w druku), Socjolingwistyczny wymiar komunikacji medycznej w nauczaniu języka polskiego jako obcego.

Sendur A.M . (2018), Analiza potrzeb jako pierwszy krok w doborze materiałów dydaktycznych, (w:) Gabryś-Barker D., Kalamarz R., Stec M. (red.), Materiały i media we współczesnej glottodydaktyce: wybrane zagadnienia. Katowice: Wydawnictwo Uniwersytetu Śląskiego, s. 27-42.

Sendur A. (2020), Certyfikacja znajomości języków obcych dla celów specjalistycznych - między teoriq a rzeczywistościq. , Neofilolog”, nr 54/1, s. 47-69.

Smuk M. (2007), Rozwijanie kompetencji tekstowej w specjalistycznych odmianach języka (na przykładzie języka francuskiego medycznego). „Języki Obce w Szkole", nr 2, s. 55-66.

Sowa M. (2016), Planowanie kursu języka specjalistycznego: problemy i wyzwania metodyczne przyszłych nauczycieli języka francuskiego. „Lingwistyka Stosowana", nr 19:4, s. 119-135.

Sowa M. (2013), Wprowadzenie. "Neofilolog", nr 41/1, s. 5-6.

Wojnicki S. (1991), Nauczanie języków obcych do celów zawodowych, Warszawa: Wiedza Powszechna. 
Zawadzka E. (2004), Nauczyciele języków obcych w dobie przemian. Kraków: Impuls.

\section{NETOGRAFIA}

http:// isap.sejm.gov.pl/isap.nsf/download.xsp/WDU20120000184/O/D20120184.pdf [DW 13.04.2021]

http://isap.sejm.gov.pl/isap.nsf/download.xsp/WDU19970280152/0/D19970152.pdf [DW 13.04.2021]

https://isap.sejm.gov.pl/isap.nsf/download.xsp/WDU20091080908/0/D20090908.pdf [DW 13.04.2021]

https://nil.org.pl/dla-lekarzy/mlodzi-lekarze/ 4282-egzaminy-z-jezyka-polskiego [DW 12.04.2021]

https://www.rp.pl/Rynek-pracy/ 310229902-Ostatnia-szansa-na-lekarzy-zeWschodu.html [DW 24.04.2021]

Received: 06.05.2021

Revised: 13.09.2021 